Article

\title{
A Methodology to Assess the Sustainability of Energy Systems through Life-Cycle Analysis and Sustainability Indicators
}

\section{Kevork Hacatoglu *, Ibrahim Dincer and Marc A. Rosen}

Faculty of Engineering and Applied Science, University of Ontario Institute of Technology, 2000 Simcoe Street North, Oshawa, Ontario, L1H 7K4, Canada

E-Mails: Kevork.Hacatoglu@uoit.ca; Ibrahim.Dincer@uoit.ca; Marc.Rosen@uoit.ca

* Author to whom correspondence should be addressed; Tel.: +1-905-721-8668; Fax: +1-905-7213178

Received: 10 August 2013 / Accepted: 31 October 2013 / Published: 01 November 2013

\begin{abstract}
Measuring progress towards sustainability is an important step in achieving sustainable development but a standard and universally accepted approach does not yet exist. Here, a novel sustainability assessment methodology for energy systems is developed using life-cycle analysis and sustainability indicators. System-related parameters are compared to sustainability-based target values to yield dimensionless sub-indicators and category indicators that are then aggregated into a composite sustainability index using weighting factors. The proposed sustainability assessment methodology is applied to a wind-battery system designed to meet the electrical energy needs of a small community in Southern Ontario. The lead-acid battery is responsible for the system's reduced affordability and high emissions of greenhouse gases, sulphur dioxide, and liquid wastes. Conversely, the system rates well according to size and other air pollutant standards. The new sustainability assessment methodology is expected to prove useful as a tool for understanding and fostering sustainable energy systems, alone or in concert with other approaches.
\end{abstract}

Keywords: assessment; climate change; economy; energy; environment; efficiency; life cycle; resources; sustainability; sustainable development. 


\section{Introduction}

The struggle to achieve a sustainable society is not unique to the modern age. Sustainability has been a goal since the earliest human civilizations. Ever since the Neolithic Revolution approximately 10,000 years ago, when human beings transitioned from mobile hunter-gatherers to agriculture and settlements, the sustainability of the local lifestyle has been essential to avoid societal collapse.

The terms 'sustainability' and 'sustainable development' are often used interchangeably despite their differences. Since 'develop' can mean 'to bring gradually to a better state,' sustainable development can be thought of as a 'continuous and sustained improvement' of a system. Development is a qualitative improvement in a system not to be confused with growth, which is a quantitative increase in physical scale. The distinction between sustainable development and sustainability is that the former is a course of action that improves the quality of life of human beings and can endure into the future. On the other hand, sustainability is a state that can be maintained into the future.

Although sustainable development is generally regarded as a positive evolutionary course, making sustainability operational is a challenge. Before a system can be declared sustainable, a method for measuring sustainability has to be in place. Otherwise, the practical value of sustainability and sustainable development diminishes.

Although there are numerous methods of assessing the sustainability of energy systems, a standard and universally accepted approach does not exist. Some studies comment on the sustainability of an energy system from a thermodynamic [1-2] or greenhouse gas [3] perspective. More comprehensive approaches that consider different aspects of sustainability but rank indicators without normalization with respect to sustainability target values are better suited to relative assessments of energy systems [4-5]. Other studies develop quantitative sustainability assessment tools that address technical, economic, social, and environmental criteria [6-9]. However, sustainability indicators are not normalized with respect to a reference state that represents limits on, for example, emissions of pollutants.

The objective of this research study is to develop a methodology to assess the sustainability of energy systems using life-cycle analysis and target values based on predicted sustainable limits. The approach is a preliminary one and considers several aspects of sustainability, including resource use, economics, and environmental considerations. The novelty of this research is the development of a life-cycle approach to assess energy system sustainability through comparisons to actual limits imposed by thermodynamics, economics, society, and the environment.

\section{Sustainability Assessment Methodology}

The proposed new sustainability assessment methodology is comprised of seven key indicators with numerous sub-indicators. The range of each indicator is between zero and one. Sub-indicators are derived by comparing a system-related parameter to a target value that is anticipated to be less than or equal to the actual parameter. In special cases where a system-related parameter is less than the target value, the sub-indicator is adjusted to zero: 


$$
B_{i, j}=\left\{\begin{array}{l}
\frac{A_{i, j}-A_{i, j, T}}{A_{i}}, A_{i, j}>A_{i, j, T} \\
0, A_{i, j} \leq A_{i, j, T}
\end{array}\right.
$$

where $B_{i, j}$ is the value of sub-indicator $j$ for category $i$ between zero (desired) and one (undesired), $A_{i, j}$ is the system-related parameter, and $A_{i, j, T}$ is the target value. Category indicators are a weighted composite of sub-indicators:

$$
\begin{gathered}
B_{i}=\sum_{j=1}^{m}\left(B_{i, j} \times W F_{i, j}\right) \\
\sum_{j=1}^{m} W F_{i, j}=1
\end{gathered}
$$

Here, $W F_{i, j}$ is the weighting factor applied to each sub-indicator, $B_{i, j}$. The sum of the weighting factors in a category $\left(W F_{i, j}\right)$ must equal one. Furthermore, $B_{i}$ is the category indicator and $m$ is the number of sub-indicators in category $i$. The overall sustainability is calculated by aggregating the category indicators and their weighting factors:

$$
\begin{gathered}
S C I=\sum_{i=1}^{n}\left(B_{i} \times W F_{i}\right) \\
\sum_{i=1}^{n} W F_{i}=1
\end{gathered}
$$

Here, $W F_{i}$ is the weighting factor applied to each category indicator, $B_{i}$. The sum of the category weighting factors $\left(W F_{i}\right)$ must equal one. In addition, $S C I$ is the sustainability composite index of the energy system and $n$ is the number of categories.

\subsection{Efficiency}

The efficiency of an energy system is a measure of its ability to convert inputs into products. The efficiency sustainability indicator is comprised of energy and exergy sub-indicators:

$$
B_{E F F}=B_{E F F, E N} \times W F_{E F F, E N}+B_{E F F, E X} \times W F_{E F F, E X}
$$

where $B_{E F F}$ is the sustainability indicator for efficiency, $B_{E F F, E N}$ and $B_{E F F, E X}$ are the sub-indicators, and $W F_{E F F, E N}$ and $W F_{E F F, E X}$ are the weighting factors for energy and exergy efficiency, respectively.

\subsubsection{Energy Efficiency}

The energy efficiency of a system is defined as the ratio of useful energy products to energy inputs and is calculated using a traditional energy analysis based on the first law of thermodynamics. All energy transformations contain irreversibilities that reduce the actual efficiency relative to the upper limit (i.e., reversible) thermodynamic efficiency. Consequently, the actual efficiency of an energy system is always less than the reversible efficiency. 
The implicit assumption in equation (1) is that the target value is less than the system-related parameter (e.g., minimizing pollution). However, unlike other pollution-related criteria, the target efficiency is greater than the actual efficiency. The energy efficiency sub-indicator is therefore calculated as

$$
B_{E F F, E N}=\frac{\left(1-A_{E F F, E N}\right)-\left(1-A_{E F F, E N, T}\right)}{1-A_{E F F, E N}}
$$

where $A_{E F F, E N}$ is the energy efficiency and $A_{E F F, E N, T}$ is the reversible (or target) energy efficiency of the system. The term $\left(1-A_{E F F, E N}\right)$ represents the actual amount of incoming energy not utilized while $\left(1-A_{E F F, E N, T}\right)$ represents the minimum amount of unavailable energy.

\subsubsection{Exergy Efficiency}

More efficient use of energy resources requires a better understanding of not just quantity but also quality of energy. In that respect, traditional energy analysis should be augmented by a second-law exergy-based approach that also considers the quality of energy.

Exergy analysis identifies the locations of energy degradation in a process and provides a superior measure of the useful work that can be extracted from a system [10]. Consequently, the weighting factor for the exergy efficiency sub-indicator $\left(W F_{E F F, E X}\right)$ should be larger than the respective factor for energy efficiency $\left(W F_{E F F, E N}\right)$. The exergy efficiency sub-indicator is calculated similarly to the energy efficiency sub-indicator from equation (5):

$$
B_{E F F, E X}=\frac{\left(1-A_{E F F, E X}\right)-\left(1-A_{E F F, E X, T}\right)}{1-A_{E F F, E X}}
$$

where $A_{E F F, E X}$ is the exergy efficiency and $A_{E F F, E X, T}$ is the reversible (or target) exergy efficiency of the system.

\subsection{Resource Availability}

This indicator measures the availability of an energy resource over the time scale for considering sustainability. Reserves $R(\mathrm{~kg})$ are the amount of a natural resource that is economic for extraction. Production $P\left(\mathrm{~kg} \mathrm{year}^{-1}\right)$ is the rate at which an energy resource is utilized. Resource availability is determined by comparing the production-to-reserves ratio of the energy source(s) driving the system to the time scale for considering sustainability $t_{S U S T}$ :

$$
\begin{gathered}
B_{R A}=\frac{A_{R A}-A_{R A, T}}{A_{R A}} \\
A_{R A}=\frac{P}{R} \\
A_{R A, T}=\frac{1}{t_{S U S T}}
\end{gathered}
$$


where $B_{R A}$ is the sustainability indicator for resource availability, $A_{R A}$ is the rate at which an energy resource is consumed, and $A_{R A, T}$ is the inverse of the time scale for considering sustainability. The time scale for considering sustainability can range from less than five years to infinity. However, equations (7) and (9) demonstrate that an infinite time scale yields an indicator equal to one as all energy resources extinguish. A more appropriate time frame for evaluating sustainability is 50 years. The disadvantage of choosing a 50-year time horizon is that it may encourage profligate use of scarce resources and may not leave a sizable margin of error if a specific resource is unexpectedly needed in the future [11].

\subsection{Economics}

Economic considerations are one of the main pillars of sustainable development [12]. The affordability and commercial viability of an energy technology will affect its adoption by communities. Hence, we can write:

$$
B_{E C O N}=B_{E C O N, C O S T} \times W F_{E C O N, C O S T}+B_{E C O N, C V} \times W F_{E C O N, C V}
$$

where $B_{E C O N}$ is the sustainability indicator for efficiency, $B_{E C O N, C O S T}$ and $B_{E C O N, C V}$ are the subindicators, and $W F_{E C O N, C O S T}$ and $W F_{E C O N, C V}$ are the weighting factors for cost and commercial viability, respectively.

\subsubsection{Cost}

Access to affordable energy services is critical for households with limited financial resources. The cost of energy delivered by the system should be compared to the median after-tax income in a region:

$$
B_{E C O N, C O S T}=\frac{A_{E C O N, C O S T}-A_{E C O N, C O S T, T}}{A_{E C O N, C O S T}}
$$

where $A_{E C O N, C O S T}$ is the cost of energy delivered by the system and $A_{E C O N, C O S T, T}$ is the cost of energy a household can afford. For example, the median after-tax annual income in Ontario in $2010 \mathrm{w}$ as $\$ 69,300$ per household [13] and no more than $10 \%$ of household expenditures should be dedicated to electricity [14].

\subsubsection{Commercial Viability}

The commercial viability of a technology over the time scale for considering sustainability is another important consideration, where mature, commercialized technologies receive a better score than non-commercialized technologies. The indicator of commercial viability $B_{E C O N, C V}$ can be set to 0 or 1 , where 0 indicates a commercially viable technology and 1 a non-commercially viable technology.

\subsection{Size Factor}

The size of the energy system can be a limiting factor depending on the application. The actual size of the system can be compared to the size that would be required for a thermodynamically reversible system. The category indicator for the size factor is therefore, 


$$
B_{S F}=B_{S F, M A S S} \times W F_{S F, M A S S}+B_{S F, A R E A} \times W F_{S F, A R E A}+B_{S F, V O L} \times W F_{S F, V O L}
$$

where $B_{S F}$ is the sustainability indicator for the size factor, $B_{S F, M A S S}, B_{S F, A R E A}$, and $B_{S F, V O L}$ are the subindicators, and $W F_{S F, M A S S}, W F_{S F, A R E A}$, and $W F_{S F, V O L}$ are the weighting factors for mass, area, and volume, respectively. The assigned value of the weighting factor for the various sub-indicators depends on the application. For stationary energy systems land area is the dominant consideration while mass and volume are more significant for mobile systems.

\subsubsection{Mass}

The mass of an energy system can be a limiting factor in certain applications such as mobile energy production systems. Thus, we can write:

$$
B_{S F, M A S S}=\frac{A_{S F, M A S S}-A_{S F, M A S S, T}}{A_{S F, M A S S}}
$$

where $A_{S F, M A S S}$ is the mass of the system and $A_{S F, M A S S, T}$ is the target mass of the system.

\subsubsection{Area}

Land and area has traditionally been an important aspect of sustainability analysis as demonstrated through concepts such as carrying capacity or ecological footprint. The land area occupied by an energy system is an important sustainability criterion for various kinds of applications. Then,

$$
B_{S F, A R E A}=\frac{A_{S F, A R E A}-A_{S F, A R E A, T}}{A_{S F, A R E A}}
$$

where $A_{S F, A R E A}$ is the area occupied by the system and $A_{S F, A R E A, T}$ is the target area of the system. For stationary applications within a bounded region, the target area may be estimated by determining the total area available per person then multiplying by a region-specific area factor that yields the total area available per person for residential energy production. The region-specific factor is a function of numerous considerations such as agricultural, industrial, and commercial land use. The factor is assumed to be $5 \%$ in this study.

\subsubsection{Volume}

The volume of an energy system can be a limiting factor in certain applications such as mobile energy production systems. In this case,

$$
B_{S F, V O L}=\frac{A_{S F, V O L}-A_{S F, V O L, T}}{A_{S F, V O L}}
$$

where $A_{S F, V O L}$ is the volume of the system and $A_{S F, V O L, T}$ is the target volume of the system.

\subsection{Global Environmental Impact}


Environmental impacts range in terms of their spatial and temporal magnitude. Long-term environmental impacts that affect the entire planet are of greatest concern to humanity. Taking these factors into account, we can write:

$$
B_{G E I}=B_{G E I, G W P} \times W F_{G E I, G W P}+B_{G E I, S O D P} \times W F_{G E I, S O D P}
$$

where $B_{G E I}$ is the sustainability indicator for global environmental impact, $B_{G E I, G W P}$ and $B_{G E I, S O D P}$ are the sub-indicators, and $W F_{G E I, G W P}$ and $W F_{G E I, S O D P}$ are the weighting factors for global warming and stratospheric ozone depletion potential, respectively.

\subsubsection{Global Warming Potential}

Anthropogenic greenhouse gas (GHG) emissions are linked to accelerated rates of climate change and global warming. The most common GHGs are carbon dioxide $\left(\mathrm{CO}_{2}\right)$, methane $\left(\mathrm{CH}_{4}\right)$, and nitrous oxide $\left(\mathrm{N}_{2} \mathrm{O}\right)$ amongst several others. Total GHG emissions can be estimated in $\mathrm{CO}_{2}$ equivalents $\left(\mathrm{CO}_{2} \mathrm{e}\right)$ by considering the global warming potential of all life-cycle GHG emissions. Thus, the global warming potential sub-indicator is

$$
B_{G E I, G W P}=\frac{A_{G E I, G W P}-A_{G E I, G W P, T}}{A_{G E I, G W P}}
$$

where $A_{G E I, G W P}$ represents life-cycle GHG emissions per capita and $A_{G E I, G W P, T}$ is the amount of energyrelated GHG emissions allotted per person multiplied by a factor for residential energy use. For example, the International Energy Agency (IEA) predicts that energy-related GHG emissions must decrease to $21.6 \mathrm{GtCO}_{2} \mathrm{e}$ to stabilize the atmospheric $\mathrm{CO}_{2}$ concentration at $450 \mathrm{ppmv}$ [15]. A global population of 7 bi llion is therefore allowed to emit approximately $3100 \mathrm{kgCO}_{2} \mathrm{e}$ of energy-related GHG emissions per person per year.

\subsubsection{Stratospheric Ozone Depletion Potential}

Ozone molecules in the stratosphere filter high-energy ultraviolet radiation from the sun that can otherwise have adverse human health and environmental impacts. Releases of halogenated hydrocarbons such as trichlorofluoromethane (also known as CFC-11 and Freon-11) that contain chlorine or bromine atoms engage in ozone-depleting chemical reactions upone ntering the stratosphere.

Although the Montreal Protocol banned the production of CFC-11 and other chlorofluorocarbons, emissions from old stocks of equipment and their long residence time in the atmosphere means that the ozone layer will recover slowly over many decades [16]. Moreover, future ozone layer depletion is expected to be driven by $\mathrm{N}_{2} \mathrm{O}$, which is an unregulated ozone-depleting substance [17]. Overall lifecycle emissions of ozone-depleting substances can be described in terms of CFC-11 equivalents by utilizing ozone depletion potentials. The stratospheric ozone depletion potential sub-indicator can be calculated as

$$
B_{G E I, S O D P}=\frac{A_{G E I, S O D P}-A_{G E I, S O D P, T}}{A_{G E I, S O D P}}
$$


where $A_{G E I, S O D P}$ represents life-cycle CFC-11 equivalent emissions and $A_{G E I, S O D P, T}$ is the target value, which is zero based on an international agreement to phase out the use of ozone-depleting substances [16].

\subsection{Air Pollution}

Air pollution is the source of a number of environmental concerns such as acid rain and groundlevel ozone formation as well as impacts on hum an health. Although there are thousands of contaminants that can cause air pollution, the US Environmental Protection Agency (EPA) has identified six criteria air pollutants to be monitored as part of its National Ambient Air Quality Standards [18]:

$$
\begin{aligned}
& B_{A P}=B_{A P, P M_{2.5}} \times W F_{A P, P M_{2.5}}+B_{A P, P M_{10}} \times W F_{A P, P M_{10}}+B_{A P, S O_{2}} \times W F_{A P, S O_{2}}+ \\
& B_{A P, C O} \times W F_{A P, C O}+B_{A P, N O_{2}} \times W F_{A P, N O_{2}}+B_{A P, O_{3}} \times W F_{A P, O_{3}}+B_{A P, P b} \times W F_{A P, P b}
\end{aligned}
$$

where $B_{A P}$ is the sustainability indicator for air pollution, $B_{A P, P M_{2.5}}, B_{A P, P M_{10}}, B_{A P, S O_{2}}, B_{A P, C O}, B_{A P, N O_{2}}$, $B_{A P, O_{3}}$, and $B_{A P, P b}$ are the sub-indicators, and $W F_{A P, P M_{2.5}}, W F_{A P, P M_{10}}, W F_{A P, S O_{2}}, W F_{A P, C O}, W F_{A P, N O_{2}}$, $W F_{A P, O_{3}}$, and $W F_{A P, P b}$ are the weighting factors for particulate matter less than $2.5 \mu \mathrm{m}\left(\mathrm{PM}_{2.5}\right)$, particulate matter less than $10 \mu \mathrm{m}\left(\mathrm{PM}_{10}\right)$, sulphur dioxide $\left(\mathrm{SO}_{2}\right)$, carbon monoxide $(\mathrm{CO})$, nitrogen dioxide $\left(\mathrm{NO}_{2}\right)$, ozone $\left(\mathrm{O}_{3}\right)$, and lead $(\mathrm{Pb})$, respectively.

\subsubsection{Particulate Matter $(\leq 2.5 \mu \mathrm{m})$}

The presence of particulate matter in the troposphere is largely a human health concern. Particulate matter smaller than $2.5 \mu \mathrm{m}$ in diameter $\left(\mathrm{PM}_{2.5}\right)$ penetrate into the gas exchange regions of the lung and cause respiratory problems in humans. Moreover, since the settling velocity of particulate matter is proportional to size, the residence time of $\mathrm{PM}_{2.5}(24 \mathrm{hr})$ is longer than that of $\mathrm{PM}_{10}(12 \mathrm{hr})$ [19]. Thus,

$$
B_{A P, P M_{2.5}}=\frac{A_{A P, P M_{2.5}}-A_{A P, P M_{2.5}, T}}{A_{A P, P M_{2.5}}}
$$

where $A_{A P, P M_{2.5}}$ represents life-cycle emissions of $\mathrm{PM}_{2.5}$ and $A_{A P, P M_{2.5}, T}$ is the ambient air quality standard of $12 \mu \mathrm{g} \mathrm{m}^{-3}$ [18].

\subsubsection{Particulate Matter $(\leq 10 \mu \mathrm{m})$}

Particulate matter smaller than $10 \mu \mathrm{m}$ in diameter $\left(\mathrm{PM}_{10}\right)$ penetrate into the deepest part of the lungs and cause respiratory problems in humans. Consequently, we can write:

$$
B_{A P, P M_{10}}=\frac{A_{A P, P M_{10}}-A_{A P, P M_{10}, T}}{A_{A P, P M_{10}}}
$$

where $A_{A P, P M_{10}}$ represents life-cycle emissions of $\mathrm{PM}_{10}$ and $A_{A P, P M_{10}, T}$ is the ambient air quality standard of $150 \mu \mathrm{g} \mathrm{m}^{-3}[18]$.

\subsubsection{Sulphur Dioxide ( $\left.\mathrm{SO}_{2}\right)$}


Combustion of fuels that contain sulphur compounds such as coal and petroleum generate $\mathrm{SO}_{2}$ emissions, which is a precursor to acid rain. Modern coal-fired power plants limit the release of $\mathrm{SO}_{2}$ to the environment through flue-gas desulphurization and low-sulphur transportation fuels are ubiquitous in the developed world but $\mathrm{SO}_{2}$ emissions still occur. The residence time of $\mathrm{SO}_{2}$ in the troposphere is 40 days. We can write for this sub-indicator:

$$
B_{A P, S O_{2}}=\frac{A_{A P, S O_{2}}-A_{A P, S O_{2}, T}}{A_{A P, S O_{2}}}
$$

where $A_{A P, S O_{2}}$ represents life-cycle emissions of $\mathrm{SO}_{2}$ and $A_{A P, S O_{2}, T}$ is the ambient air quality standard of $190 \mu \mathrm{g} \mathrm{m}^{-3}[18]$.

\subsubsection{Carbon Monoxide (CO)}

The primary source of $\mathrm{CO}$ emissions is incomplete combustion of fossil fuels within internal combustion engines. $\mathrm{CO}$ is a precursor to ground-level ozone formation and photochemical smog. Unlike $\mathrm{CO}_{2}$, which has a residence time measured in years, $\mathrm{CO}$ is more reactive and has a residence time in the troposphere of 65 days. The $\mathrm{CO}$ sub-indicator is therefore,

$$
B_{A P, C O}=\frac{A_{A P, C O}-A_{A P, C O, T}}{A_{A P, C O}}
$$

where $A_{A P, C O}$ represents life-cycle emissions of $\mathrm{CO}$ and $A_{A P, C O, T}$ is the ambient air quality standard of $10 \mathrm{mg} \mathrm{m}^{-3}[18]$.

\subsubsection{Nitrogen Dioxide $\left(\mathrm{NO}_{2}\right)$}

High-temperature combustion of fossil fuels with air leads to the formation of $\mathrm{NO}_{2}$, which is a precursor to acid rain and the creation of ground-level ozone. $\mathrm{NO}_{2}$ is an oxidizing agent and has a short residence time in the troposphere of 1 day. Consequently, the $\mathrm{NO}_{2}$ sub-indicator can be calculated as

$$
B_{A P, N O_{2}}=\frac{A_{A P, \mathrm{NO}_{2}}-A_{A P, \mathrm{NO}_{2}, \mathrm{~T}}}{A_{A P, \mathrm{NO}_{2}}}
$$

where $A_{A P, N O_{2}}$ represents life-cycle emissions of $\mathrm{NO}_{2}$ and $A_{A P, N O_{2}, T}$ is the ambient air quality standard of $100 \mu \mathrm{g} \mathrm{m}^{-3}[18]$.

\subsubsection{Ground-Level Ozone $\left(\mathrm{O}_{3}\right)$}

Although ozone molecules in the stratosphere perform essential life-supporting services by filtering high-energy ultraviolet radiation, ozone in the troposphere (or ground-level ozone) has an adverse impact on human health. The residence time of ozone in the troposphere is 60 days. The ground-level $\mathrm{O}_{3}$ sub-indicator is therefore,

$$
B_{A P, O_{3}}=\frac{A_{A P, O_{3}}-A_{A P, O_{3}, T}}{A_{A P, O_{3}}}
$$


where $A_{A P, O_{3}}$ represents life-cycle emissions of ground-level $\mathrm{O}_{3}$ and $A_{A P, O_{3}, T}$ is the ambient air quality standard of $150 \mu \mathrm{g} \mathrm{m}^{-3}[18]$.

\subsubsection{Lead $(\mathrm{Pb})$}

There are several toxic air pollutants emitted by industrial processes that have adverse effects on human health. The EPA identifies lead as a criteria air pollutant that should be closely monitored. There are no significant chemical processes that accelerate the removal of atmospheric lead. For lead particles with a mass size distribution of 0.1-1.0 $\mu \mathrm{m}$, the mean residence time in the troposphere is approximately 3 days [20]. In this case,

$$
B_{A P, P b}=\frac{A_{A P, P b}-A_{A P, P b, T}}{A_{A P, P b}}
$$

where $A_{A P, P b}$ represents life-cycle emissions of lead and $A_{A P, P b, T}$ is the ambient air quality standard of $0.15 \mu \mathrm{g} \mathrm{m}^{-3}[18]$.

\subsection{Water Pollution}

Water ecosystems are an integral part of the environment and are also utilized by humans for drinking water, food, and leisure. Industrial effluents and agricultural runoff are sources of water pollution that can disrupt aquatic ecosystems. Taking these factors into account:

$$
B_{W P}=B_{W P, E P} \times W F_{W P, E P}+B_{W P, F A E T P} \times W F_{W P, F A E T P}
$$

where $B_{W P}$ is the sustainability indicator for water pollution, $B_{W P, E P}$ and $B_{W P, F A E T P}$ are the subindicators, and $W F_{W P, E P}$ and $W F_{W P, F A E T P}$ are the weighting factors for eutrophication and freshwater aquatic ecotoxicity potential, respectively.

\subsubsection{Eutrophication Potential}

Eutrophication in aquatic ecosystems is due to excess nutrient loads. Phosphorus is often a limiting nutrient in eutrophic systems. The critical load for phosphate $\left(\mathrm{PO}_{4}{ }^{3-}\right)$ in assessing eutrophication of a body of water is $0.15 \mathrm{mg} \mathrm{L}^{-1}$ [21]. The eutrophication potential sub-indicator can be written as

$$
B_{W P, E P}=\frac{A_{W P, E P}-A_{W P, E P, T}}{A_{W P, E P, T}}
$$

where $A_{W P, E P}$ represents life-cycle emissions of phosphates and $A_{W P, E P, T}$ is the critical load of phosphate.

\subsubsection{Freshwater Aquatic Ecotoxicity Potential}

Water emissions may contain harmful substances that are toxic to aquatic organisms. The ecotoxicity of emissions can be converted to common units of 1,4-dichlorobenzene (1,4-DCB) based on equivalency factors. Consequently, 


$$
B_{W P, F A E T P}=\frac{A_{W P, F A E T P}-A_{W P, F A E T P, T}}{A_{W P, F A E T P, T}}
$$

where $A_{W P, F A E T P}$ represents life-cycle emissions of 1,4-DCB and $A_{W P, F A E T P, T}$ is the predicted no-effect concentration of 1,4-DCB, which is $20 \mathrm{mg} \mathrm{m}^{-3}$ [21].

\subsection{Discussion}

There are three advantages of this new approach to sustainability assessment. The first is that the assessment considers a diverse range of factors that contribute to sustainability. Each of the seven categories is an important criterion of sustainability such as land area (related to carrying capacity), affordability, global environmental emissions, and air quality standards. The second advantage is that the method employs life-cycle analysis to calculate several sub-indicators. Lastly, the approach compares system-related parameters to sustainability-based target values, which allows the user to determine how close the system approaches sustainability for each sub-indicator. The combination of these three features produces a novel quantitative sustainability assessment tool. In addition, aggregating sub-indicators into category indicators and an overall sustainability composite index is a simple and helpful tool for decision makers. Nevertheless, users and decision makers need to be aware that there is an inevitable loss of information when aggregating indicators [22] and considering only the sustainability composite index can lead to an incomplete picture of the system.

There are also limitations with the sustainability assessment methodology developed in this study. Despite the diverse range of category indicators, there are other aspects of sustainability not considered here. For example, social and political issues such as public acceptance and political support are not part of the assessment. From a m ore technical perspective, the seven categories included in the assessment were chosen because of their importance to sustainability and our ability to develop associated indicators. For example, there is no category for soil emissions or production of solid wastes largely because there are no target values available. Terrestrial ecotoxicity is an impact category in life-cycle assessment but deriving an appropriate target value is a significant obstacle.

\section{Case Study}

The sustainability assessment approach developed above will be implemented to assess the sustainability of a wind-battery system designed to meet the electricity needs of a small community in Southern Ontario.

\subsection{System Description}

A wind turbine that converts the kinetic energy of wind to electricity is proposed to meet the electric energy needs of a 50-household community in Ontario. The wind turbine is integrated with a lead-acid battery (Figure 1) to ensure the community has a reliable supply of electricity during periods of low wind activity. 
Figure 1. Schematic of the wind-battery system.

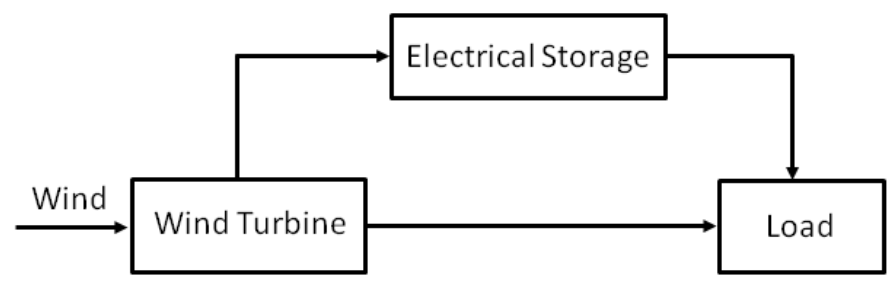

When the power delivered by the wind turbine is greater than the load, the battery enters a charging mode. When there is unmet demand, the battery begins to discharge. The size of the wind turbine is selected such that at the end of one year the net charge in the battery is positive and the community does not need to import external electrical energy.

\subsection{Analysis}

A thermodynamic model of the system was developed using the Engineering Equation Solver (EES) software. The model was run for 365 days with three different input variables: 1) electricity demand per household, 2) wind speed, and 3) ambient temperature. The daily average electricity demand of a household in Ontario was estimated according to a study by Saldanha and Beausoleil-Morrison [23].

The wind speed (WS ) profile of an average site can be modeled based on a Weibull probability density function with a shape parameter $(k)$ between 1.5 and 2.5 (dimensionless) and a scale parameter $(c)$ between 5 and $10 \mathrm{~m} \mathrm{~s}^{-1}$ [24]. For the probability function we can write:

$$
f(W S)=\frac{k}{c}\left(\frac{W S}{c}\right)^{k-1} \exp \left[-\left(\frac{W S}{c}\right)^{k}\right]
$$

The daily average wind speed and electricity demand per household in Southern Ontario is shown in Figure 2. Although wind speed fluctuates between 0 and $20 \mathrm{~m} \mathrm{~s}^{-1}$ the demand per household is more tightly bound between 0.8 and $4 \mathrm{~kW}$. This highlights the need for energy storage.

Figure 2. Daily wind speed and power needs over one year for a typical household in Ontario (day "1" corresponds to August 1, 2009).

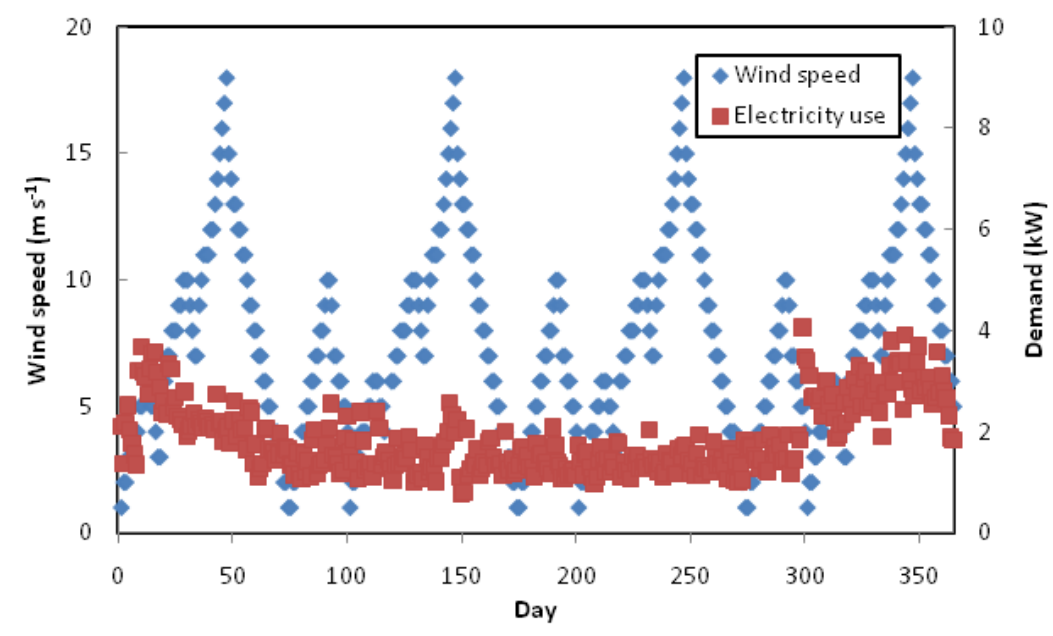


The kinetic energy ( $\dot{E}_{\text {Wind }}$ ) of wind is directly proportional to the swept area of the turbine blades and to the cube of wind speed:

$$
\dot{E}_{\text {Wind }}=\frac{1}{2} \rho \pi R^{2}(W S)^{3}
$$

where $\rho$ is the density of air and $R$ is the rotor radius. The actual shaft work generated by the wind turbine $\left(\dot{W}_{W T}\right)$ depends on the power coefficient $\left(C_{P}\right)$ and mechanical efficiency $\left(\eta_{\text {Mech }}\right)$ :

$$
\dot{W}_{W T}=\frac{1}{2} \rho \pi R^{2}(W S)^{3} C_{P} \eta_{M e c h}
$$

The energy $(\eta)$ and exergy $(\psi)$ efficiency of the system is the ratio of products to inputs. Included as a product is the net work added to the battery:

$$
\begin{gathered}
\eta=\frac{\dot{W}_{\text {Load }}+\dot{W}_{\text {Battery }}}{\dot{E}_{\text {Wind }}} \\
\psi=\frac{\dot{W}_{\text {Load }}+\dot{W}_{\text {Battery }}}{\dot{E} x_{\text {Wind }}}
\end{gathered}
$$

where $\dot{W}_{\text {Load }}$ denotes the community electrical power demand, $\dot{W}_{\text {Battery }}$ the net work added to the battery, and $\dot{E} x_{\text {Wind }}$ the exergy of wind. The values of several parameters used in the analysis of the wind-battery system are defined in Table 1.

Table 1. Wind-battery model parameters.

\begin{tabular}{|l|l|}
\hline Parameter & Value \\
\hline Betz limit for a wind turbine & 0.59 \\
Charging efficiency of the battery & 0.85 \\
Cut-in wind speed & $5 \mathrm{~m} \mathrm{~s}^{-1}$ \\
Cut-out wind speed & $23 \mathrm{~m} \mathrm{~s}^{-1}$ \\
Discharging efficiency of the battery & 0.85 \\
Electric generator efficiency & 0.92 \\
Mechanical efficiency of a wind turbine & 0.60 \\
Number of households & 50 \\
Number of people per household & 4 \\
Power coefficient of a wind turbine & 0.45 \\
Rated wind speed & $15 \mathrm{~m} \mathrm{~s}^{-1}$ \\
Rotor radius & $19 \mathrm{~m}^{2}$ \\
\hline
\end{tabular}

A rotor radius of $19 \mathrm{~m}$ was selected to ensure the net charge in the battery after one year is positive. Furthermore, the wind turbine does not generate any power below the cut-in or above the cut-out wind speed. The turbine generates its rated power at any wind speed above the rated wind speed. The rated power of the wind turbine is $565 \mathrm{~kW}$.

\subsection{Sustainability Assessment}


A life-cycle analysis and impact assessment of the wind-battery model illustrated in Figure 1 was conducted using SimaPro to determine the magnitude of global warming, stratospheric ozone depletion, eutrophication, aquatic ecotoxicity, and criteria air pollutants emitted by the system. Lifecycle emissions as well as other parameters required to conduct the sustainability assessment are presented in Table 2.

Table 2. Life-cycle emissions and other parameters related to a wind turbine and lead-acid battery.

\begin{tabular}{|c|c|c|}
\hline Parameter & Wind turbine & Lead-acid battery \\
\hline Capital cost & $\$ 1500 \mathrm{~kW}^{-1}$ & $\$ 300 \mathrm{kWh}^{-1}$ \\
\hline Carbon monoxide & $37.7 \times 10^{-6} \mathrm{~kg} \mathrm{CO} \mathrm{MJ}{ }^{-1}$ & $34.5 \times 10^{-3} \mathrm{~kg} \mathrm{CO} \mathrm{kg}^{-1}$ \\
\hline Eutrophication potential & $2.23 \times 10^{-5} \mathrm{~kg} \mathrm{PO}_{4}{ }^{3-} \mathrm{MJ}^{-1}$ & $8.08 \times 10^{-3} \mathrm{~kg} \mathrm{PO}_{4}^{3-} \mathrm{kg}^{-1}$ \\
\hline Freshwater aquatic ecotoxicity potential & $0.0111 \mathrm{~kg} \mathrm{DCB} \mathrm{MJ}^{-1}$ & $1.96 \mathrm{~kg} \mathrm{DCB} \mathrm{kg}^{-1}$ \\
\hline Global warming potential & $0.0086 \mathrm{~kg} \mathrm{CO}_{2} \mathrm{e} \mathrm{MJ}^{-1}$ & $1.47 \mathrm{~kg} \mathrm{CO}_{2} \mathrm{e} \mathrm{kg}^{-1}$ \\
\hline Lead & $46.9 \times 10^{-9} \mathrm{~kg} \mathrm{~Pb} \mathrm{MJ}^{-1}$ & $30.8 \times 10^{-6} \mathrm{~kg} \mathrm{~Pb} \mathrm{~kg}^{-1}$ \\
\hline Lifetime & $20 \mathrm{yr}$ & $10 \mathrm{yr}$ \\
\hline en dioxide & $20.1 \times 10^{-6} \mathrm{~kg} \mathrm{NO}_{2} \mathrm{MJ}^{-1}$ & $3.48 \times 10^{-3} \mathrm{~kg} \mathrm{NO}_{2} \mathrm{~kg}^{-1}$ \\
\hline Ozon & $16.1 \times 10^{-9} \mathrm{~kg} \mathrm{O}_{3} \mathrm{MJ}^{-1}$ & $495 \times 10^{-9} \mathrm{~kg} \mathrm{O}_{3} \mathrm{~kg}^{-1}$ \\
\hline $\operatorname{er}\left(\mathrm{PM}_{2.5}\right)$ & $6.75 \times 10^{-6} \mathrm{~kg} \mathrm{PM}_{2.5} \mathrm{MJ}^{-1}$ & $0.83 \times 10^{-3} \mathrm{~kg} \mathrm{PM}_{2.5} \mathrm{~kg}^{-1}$ \\
\hline Particulate matter $\left(\mathrm{PM}_{10}\right)$ & $7.11 \times 10^{-6} \mathrm{~kg} \mathrm{PM}_{10} \mathrm{MJ}^{-1}$ & $1.42 \times 10^{-3} \mathrm{~kg} \mathrm{PM}_{10} \mathrm{~kg}^{-1}$ \\
\hline Stra & $6.46 \times 10^{-9} \mathrm{~kg} \mathrm{Cl}$ & $7.01 \times 10^{-7} \mathrm{~kg} \mathrm{CFC}-11 \mathrm{~kg}^{-1}$ \\
\hline Sulphur dioxide & $25.8 \times 10^{-6} \mathrm{~kg} \mathrm{SO}_{2} \mathrm{MJ}^{-1}$ & $22.4 \times 10^{-3} \mathrm{~kg} \mathrm{SO}_{2} \mathrm{~kg}^{-1}$ \\
\hline
\end{tabular}

Many of the parameters for the wind turbine are on a per MJ basis over the lifetime of the installation. On the other hand, the parameters for the lead-acid battery are per kg of battery. The stratospheric ozone depletion potential parameter generated by SimaPro was adjusted to account for the ozone depletion potential of $\mathrm{N}_{2} \mathrm{O}$ calculated by Ravishankara et al. [17].

The user conducting the sustainability assessment has to assign weighting factors for each of the sub-indicators and category indicators. The values of each of the weighting factors used in the study are shown in Table 3.

This study assumes equivalent weighting factors for sub-indicators within a category (column 3 , Table 3) as well as for category weighting factors (column 4). Similar assumptions are made in other quantitative sustainability assessments $[6,9]$. However, the weighting factors for the mass and volume sub-indicators in the size factor category are set to zero because the stationary wind-battery energy system is constrained by land area. The mass and volume of the system therefore has no effect on its sustainability from a size perspective.

\section{Results and Discussion}

\subsection{Physical Modeling Results}

Over the course of one year the battery went through several charge/discharge cycles (Figure 3). At the design conditions specified in Table 1, the net power input to the battery is $4837 \mathrm{~kW}$ after one year. A comparison of Figures 2 and 3 demonstrates that the battery is charged when wind speeds are high and discharged when wind speeds are low. 
Table 3. Weighting factors used in the sustainability assessment.

\begin{tabular}{|c|c|c|c|}
\hline Category & Sub-indicator & Weighting factor & Category weighting factor \\
\hline Efficiency & $\begin{array}{l}\text { Energy } \\
\text { Exergy }\end{array}$ & $\begin{array}{l}0.50 \\
0.50\end{array}$ & 0.143 \\
\hline $\begin{array}{l}\text { Resource } \\
\text { availability }\end{array}$ & - & - & 0.143 \\
\hline Economics & $\begin{array}{l}\text { Cost } \\
\text { Commercial } \\
\text { viability }\end{array}$ & $\begin{array}{l}0.50 \\
0.50\end{array}$ & 0.143 \\
\hline Size factor & $\begin{array}{l}\text { Mass } \\
\text { Area } \\
\text { Volume }\end{array}$ & $\begin{array}{l}- \\
1.00 \\
-\end{array}$ & 0.143 \\
\hline $\begin{array}{l}\text { Global } \\
\text { environmental } \\
\text { impact }\end{array}$ & $\begin{array}{l}\text { GWP } \\
\text { SODP }\end{array}$ & $\begin{array}{l}0.50 \\
0.50\end{array}$ & 0.143 \\
\hline Air pollution & $\begin{array}{l}\mathrm{PM}_{2.5} \\
\mathrm{PM}_{10} \\
\mathrm{SO}_{2} \\
\mathrm{CO} \\
\mathrm{NO}_{2} \\
\mathrm{O}_{3} \\
\mathrm{~Pb}\end{array}$ & $\begin{array}{l}0.143 \\
0.143 \\
0.143 \\
0.143 \\
0.143 \\
0.143 \\
0.143\end{array}$ & 0.143 \\
\hline Water pollution & $\begin{array}{l}\text { EP } \\
\text { FAETP }\end{array}$ & $\begin{array}{l}0.50 \\
0.50\end{array}$ & 0.143 \\
\hline
\end{tabular}

Figure 3. Power added to the battery during one year of operation of the wind-battery energy system (day “1” corresponds to August 1, 2009).

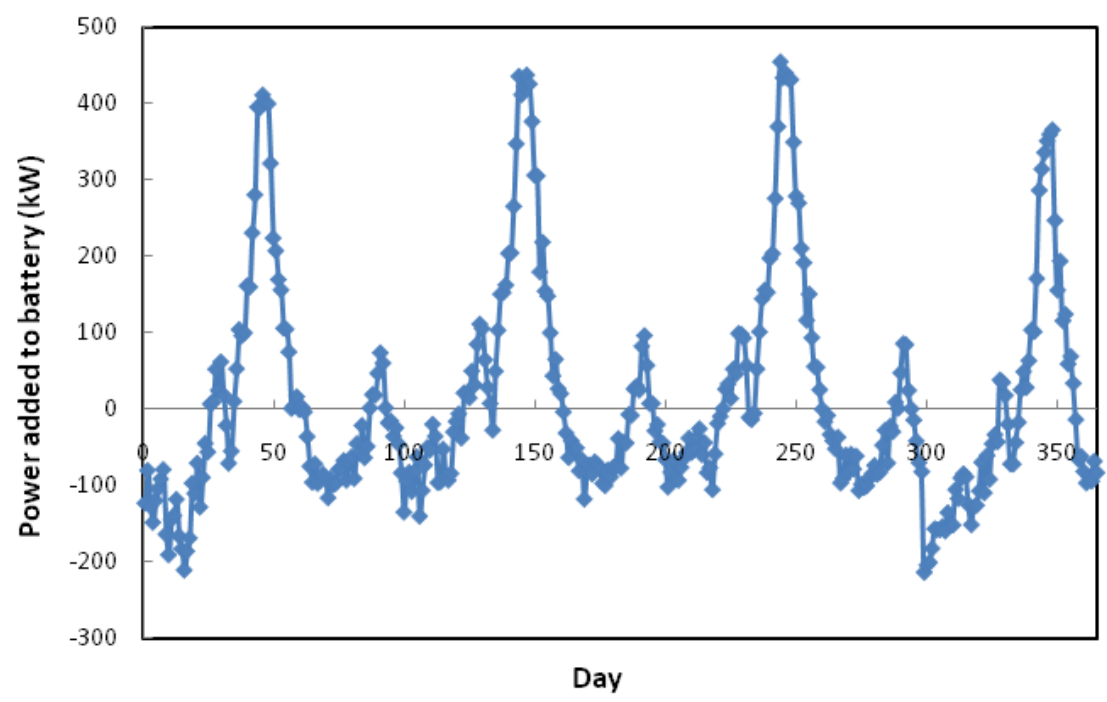

The required capacity of the battery however can only be determined by calculating the minimum and maximum charge of the battery over the course of the year (Figure 4). The curve in Figure 4 shows that the lead-acid battery should have a minimum capacity of approximately $76,000 \mathrm{kWh}$ to ensure a reliable supply of electricity through days 1-25 whereas the capacity should not exceed 180,000 kWh, as is achieved through days 250-300. 
Figure 4. Accumulation of energy in the battery during one year of operation of the windbattery energy system (day “1” corresponds to August 1, 2009).

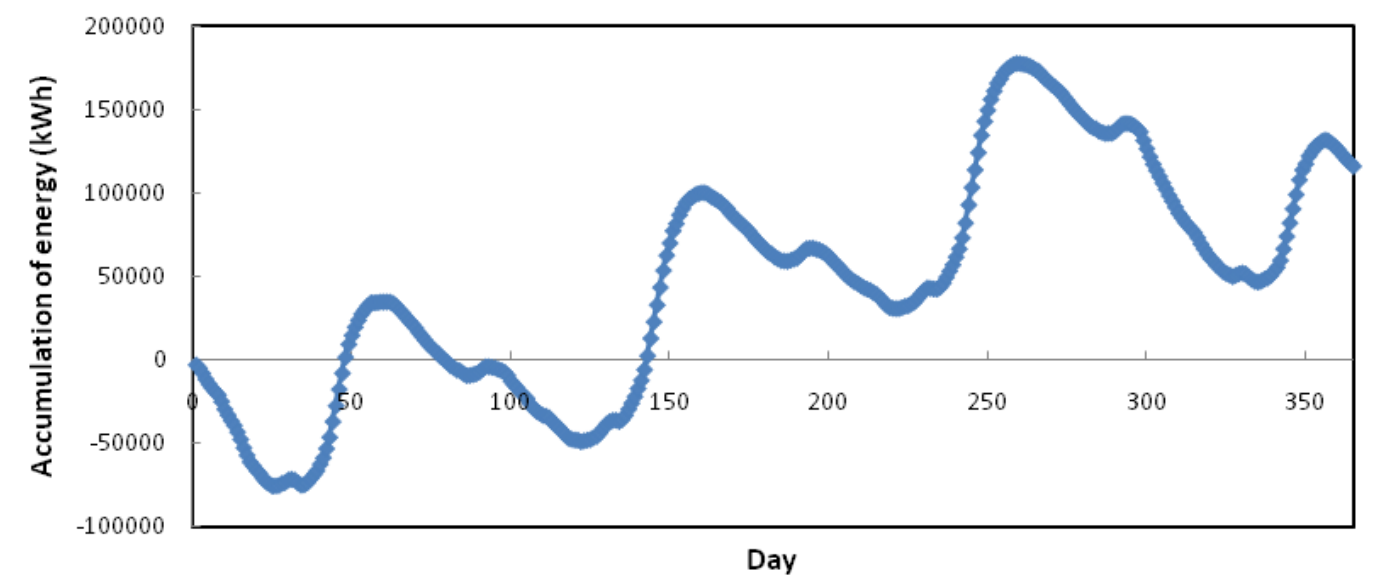

The overall energy and exergy efficiency of the wind-battery system after the 1-year period is 0.20 and 0.33 , r espectively. Conversely, the reversible energy and exergy efficiency is 0.55 and 0.92 , respectively. The exergy destruction rate of the wind turbine is $71,727 \mathrm{~kW}$, which is $92 \%$ of the total exergy destruction rate $(78,050 \mathrm{~kW})$ while charging/discharging of the battery accounts for the other $8 \%(6323 \mathrm{~kW})$.

\subsection{Sustainability Assessment Results}

The output of the sustainability assessment model for the wind-battery system is presented in Table 4. The sustainability composite index at the bottom of the table is calculated using equation (3) and the weighting factors from Table 3.

Since wind turbines and lead-acid batteries are both mature technologies, the commercial viability sub-indicator was adjusted to 0 . On the other hand, the system is not very affordable to households since $B_{E C O N, C O S T}$ is quite high at 0.92 . The annual cost to a household is $\$ 87,150$, which easily surpasses the median after-tax income of a household in Ontario. The primary contributing factor is the exorbitant cost of the battery and its very large size to guarantee a continuous and reliable supply of power to the community.

The size of the battery is also responsible for over $95 \%$ of life-cycle GHG emissions. Reducing the size of the battery to the minimum capacity of 76,000 kWh (Figure 4) decreases annual cost from $\$ 87,150$ to $\$ 37,990$ per household and annual life-cycle GHG emissions from 1710 to $770 \mathrm{~kg} \mathrm{CO}_{2}$ e per person. However, these values are still high and another drawback is that a portion of wind-generated power will have to be discarded. Paradoxically, the sustainability of this system might improve with a small back-up gas-fired generator.

The only air pollutant to exceed ambient air quality standards is $\mathrm{SO}_{2}$ because the manufacture of lead-acid batteries requires sulphuric acid. Once again, the amount of sulphuric acid required in the manufacturing process is very high due to the large size of the battery. Similarly, the freshwater aquatic ecotoxicity potential exceeds the critical load concentration largely due to water emissions from the lead-acid battery production process. 
Table 4. Results of the sustainability assessment for the wind-battery system.

\begin{tabular}{|c|c|c|c|c|c|c|c|}
\hline Category & Sub-indicator & $\begin{array}{l}\text { Wind } \\
\text { turbine }\end{array}$ & Battery & Total & Target & $B_{i, j}$ & $B_{i}$ \\
\hline Efficiency & $\begin{array}{l}\text { Energy } \\
\text { Exergy }\end{array}$ & - & - & $\begin{array}{l}0.803 \\
0.668\end{array}$ & $\begin{array}{l}0.453 \\
0.0783\end{array}$ & $\begin{array}{l}0.44 \\
0.88\end{array}$ & 0.66 \\
\hline $\begin{array}{l}\text { Resource } \\
\text { availability }\end{array}$ & - & - & - & 0.001 & 0.02 & 0 & 0 \\
\hline Economics & $\begin{array}{l}\text { Cost } \\
\text { CV }\end{array}$ & $\begin{array}{l}1577 \\
-\end{array}$ & $\begin{array}{l}85576 \\
-\end{array}$ & $\begin{array}{l}87150 \\
-\end{array}$ & $\begin{array}{l}6930 \\
-\end{array}$ & $\begin{array}{l}0.92 \\
0\end{array}$ & 0.46 \\
\hline Size factor & $\begin{array}{l}\text { Mass } \\
\text { Area } \\
\text { Volume }\end{array}$ & $\begin{array}{l}- \\
28 \\
-\end{array}$ & $\begin{array}{l}- \\
13 \\
-\end{array}$ & $\begin{array}{l}- \\
41 \\
-\end{array}$ & $\begin{array}{l}- \\
401 \\
-\end{array}$ & $\begin{array}{l}- \\
0 \\
-\end{array}$ & 0 \\
\hline $\begin{array}{l}\text { Global } \\
\text { environmental } \\
\text { impact }\end{array}$ & $\begin{array}{l}\text { GWP } \\
\text { SODP }\end{array}$ & $\begin{array}{l}77 \\
5.2 \times 10^{-9}\end{array}$ & $\begin{array}{l}1633 \\
7.8 \times 10^{-4}\end{array}$ & $\begin{array}{l}1710 \\
0.00084\end{array}$ & $\begin{array}{l}930 \\
0\end{array}$ & $\begin{array}{l}0.46 \\
1.0\end{array}$ & 0.73 \\
\hline Air pollution & $\begin{array}{l}\mathrm{PM}_{2.5} \\
\mathrm{PM}_{10} \\
\mathrm{SO}_{2} \\
\mathrm{CO} \\
\mathrm{NO}_{2} \\
\mathrm{O}_{3} \\
\mathrm{~Pb}\end{array}$ & $\begin{array}{l}3.4 \times 10^{-11} \\
1.8 \times 10^{-11} \\
5.2 \times 10^{-9} \\
1.2 \times 10^{-8} \\
1.0 \times 10^{-10} \\
3.0 \times 10^{-11} \\
7.1 \times 10^{-13}\end{array}$ & $\begin{array}{l}5.2 \times 10^{-10} \\
4.5 \times 10^{-10} \\
5.7 \times 10^{-7} \\
1.4 \times 10^{-6} \\
2.2 \times 10^{-9} \\
1.1 \times 10^{-10} \\
5.8 \times 10^{-11}\end{array}$ & $\begin{array}{l}5.6 \times 10^{-10} \\
4.7 \times 10^{-10} \\
5.7 \times 10^{-7} \\
1.4 \times 10^{-6} \\
2.3 \times 10^{-9} \\
1.4 \times 10^{-10} \\
5.9 \times 10^{-11}\end{array}$ & $\begin{array}{l}1.2 \times 10^{-8} \\
1.5 \times 10^{-7} \\
1.9 \times 10^{-7} \\
1.0 \times 10^{-5} \\
1.0 \times 10^{-7} \\
1.5 \times 10^{-7} \\
1.5 \times 10^{-10}\end{array}$ & $\begin{array}{l}0 \\
0 \\
0.66 \\
0 \\
0 \\
0 \\
0\end{array}$ & 0.094 \\
\hline $\begin{array}{l}\text { Water } \\
\text { pollution }\end{array}$ & $\begin{array}{l}\text { EP } \\
\text { FAETP }\end{array}$ & $\begin{array}{l}1.1 \times 10^{-6} \\
2.2 \times 10^{-4}\end{array}$ & $\begin{array}{l}5.0 \times 10^{-5} \\
0.0050\end{array}$ & $\begin{array}{l}5.1 \times 10^{-5} \\
0.0052\end{array}$ & $\begin{array}{l}1.5 \times 10^{-4} \\
2.0 \times 10^{-5}\end{array}$ & $\begin{array}{l}0 \\
1.0\end{array}$ & 0.50 \\
\hline \multicolumn{7}{|c|}{ Sustainability Composite Index } & 0.35 \\
\hline
\end{tabular}

The limitations of the approach have an effect on the final results (i.e., overall sustainability). For example, the air pollution category is limited to only seven different air contaminants. There could be a significant amount of air emissions of a toxic compound in the wind turbine or battery life cycle that renders the system unsustainable. The approach is most likely inapplicable to energy systems that generate a significant amount of pollutants that are not considered in the analysis (e.g., formation of dioxins from incineration of municipal solid waste). However, case-specific sub-indicators can always be added to the general assessment framework by the user.

\section{Conclusions}

A new methodology to assess the sustainability of energy systems based on life-cycle analysis and seven different categories of indicators is developed here. The novelty of the approach is its diverse range of indicators, life-cycle perspective, and comparison of system-related parameters to sustainability-based targets. The approach is applied to a wind-battery system intended to supply a 50household community in Southern Ontario with electrical energy. The system rates well according to size and most air pollution criteria. However, the size of the lead-acid battery required to ensure a continuous and reliable supply of electricity is prohibitive from a cost, $\mathrm{GHG}, \mathrm{SO}_{2}$, and aquatic ecotoxicity perspective. The sustainability composite index of the system could be improved by substituting the battery with other storage technologies. Future work will focus on i mproving the 
methodology such as the selection of weighting factors, improving indicator measurement, and incorporating additional indicators to make the approach more comprehensive.

\section{Acknowledgments}

The authors gratefully acknowledge the support provided by the Natural Sciences and Engineering Research Council of Canada.

\section{Conflict of Interest}

The authors declare no conflict of interest.

\section{Nomenclature}

$\begin{array}{ll}A & \text { System-related parameter } \\ B & \text { Sustainability indicator } \\ c & \text { Scale parameter, } \mathrm{m} \mathrm{s}^{-1} \\ C_{P} & \text { Power coefficient } \\ \dot{E} & \text { Kinetic energy rate, } \mathrm{kW} \\ \dot{E} x & \text { Exergy rate, } \mathrm{kW} \\ k & \text { Shape parameter } \\ R & \text { Rotor radius, } \mathrm{m} \\ S C I & \text { Sustainability composite index } \\ t & \text { Time, yr } \\ W S & \text { Wind speed, } \mathrm{m} \mathrm{s}^{-1} \\ \dot{W} & \text { Work rate, } \mathrm{kW} \\ W F & \text { Weighting factor }\end{array}$

\section{Greek Letters}

$\begin{array}{ll}\eta & \text { Energy efficiency, \% } \\ \psi & \text { Exergy efficiency, \% } \\ \rho & \text { Density, } \mathrm{kg} \mathrm{m}^{-3}\end{array}$

\section{Subscripts}

$\begin{array}{ll}e & \text { Equivalents } \\ i & \text { Category indicator } \\ j & \text { Sub-indicator } \\ m & \text { Number of sub-indicators } \\ n & \text { Number of category indicators } \\ T & \text { Target }\end{array}$

\section{Abbreviations}

$\begin{array}{ll}\text { AP } & \text { Air pollution } \\ \text { CFC } & \text { Chlorofluorocarbon } \\ \text { CV } & \text { Commercial viability } \\ \text { DCB } & \text { Dichlorobenzene } \\ \text { ECON } & \text { Economics }\end{array}$




$\begin{array}{ll}\text { EFF } & \text { Efficiency } \\ \text { EN } & \text { Energy } \\ \text { EP } & \text { Eutrophication potential } \\ \text { EPA } & \text { Environmental Protection Agency } \\ \text { EX } & \text { Exergy } \\ \text { FAETP } & \text { Freshwater aquatic ecotoxicity potential } \\ \text { GHG } & \text { Greenhouse gas } \\ \text { GEI } & \text { Global environmental impact } \\ \text { GWP } & \text { Global warming potential } \\ \text { IEA } & \text { International Energy Agency } \\ \text { IPCC } & \text { Intergovernmental Panel on Climate Change } \\ \text { PM } & \text { Particulate matter } \\ \text { RA } & \text { Resource availability } \\ \text { SF } & \text { Size factor } \\ \text { SODP } & \text { Stratospheric ozone depletion potential } \\ \text { VOL } & \text { Volume } \\ \text { WP } & \text { Water pollution } \\ \text { WT } & \text { Wind turbine }\end{array}$

\section{Chemical Compounds}

$\begin{array}{ll}\mathrm{CH}_{4} & \text { Methane } \\ \mathrm{CO} & \text { Carbon monoxide } \\ \mathrm{CO}_{2} & \text { Carbon dioxide } \\ \mathrm{NO}_{2} & \text { Nitrogen dioxide } \\ \mathrm{N}_{2} \mathrm{O} & \text { Nitrous oxide } \\ \mathrm{O}_{3} & \text { Ozone } \\ \mathrm{Pb} & \text { Lead } \\ \mathrm{PO}_{4}{ }^{3-} & \text { Phosphate } \\ \mathrm{SO}_{2} & \text { Sulphur dioxide }\end{array}$

\section{References and Notes}

1. Dewulf, H.; Van Langenhove, H.; Mulder, J.; van den Berg, M.M.D. Illustrations towards quantifying the sustainability of technology. Green Chemistry 2000, 2, 108-114.

2. Ferrari, S.; Genoud, S.; Lesourd, J. Thermodynamics and economics: towards exergy-based indicators of sustainable development. Swiss Journal of Economics and Statistics 2001, 137, 319-336.

3. Zvolinschi, A.; Kjelstrup, S.; Bolland, O.; van der Kooi, H.J. Exergy sustainability indicators as a tool in industrial ecology. Journal of Industrial Ecology 2007, 11, 85-98.

4. Evans, A.; Strezov, V.; Evans, T.J. Assessment of sustainability indicators for renewable energy technologies. Renewable and Sustainable Energy Reviews 2009, 13, 1082-1088.

5. Gnanapragasam, N.V.; Reddy, B.V.; Rosen, M.A. A methodology for assessing the sustainability of hydrogen production from solid fuels. Sustainability 2010, 2, 1472-1491.

6. Afgan, N.H.; Carvalho, M.G.; Hovanov, N.V. Energy system assessment with sustainability indicators. Energy Policy 2000, 28, 603-612.

7. Afgan, N.H.; Carvalho, M.G. Multi-criteria assessment of new and renewable energy power plants. Energy 2002, 27, 739-755. 
8. Afgan, N.H. Sustainability paradigm: intelligent energy system. Sustainability 2010, 2, 38123830 .

9. Frangopoulos, C.A.; Keramioti, D.E. Multi-criteria evaluation of energy systems with sustainability considerations. Entropy 2010, 12, 1006-1020.

10. Dincer, I.; Rosen, M.A. Exergy: Energy, Environment and Sustainable Development, 2nd ed.; Elsevier: Oxford, UK, 2013.

11. Graedel, T.E.; Allenby, B.R. Industrial Ecology and Sustainable Engineering; Prentice Hall: New Jersey, USA, 2010.

12. Kates, R.W.; Parris, T.M.; Leiserowitz, A.A. What is sustainable development? Environment 2005, 47, 8-21.

13. Statistics Canada. Median after-tax income, by economic family type, 2010 constant dollars, annual (CANSIM Table 202-0605). Ottawa, Canada, 2012.

14. Fankhauser, S.; Tepic, S. Can poor consumers pay for energy and water? An affordability analysis for transition countries. Energy Policy 2007, 35, 1038-1049.

15. International Energy Agency (IEA). World Energy Outlook 2011; Organization for Economic Cooperation and Development, Paris, France, 2011.

16. Intergovernmental Panel on Climate Change (IPCC). Safeguarding the Ozone Layer and the Global Climate System; Cambridge University Press: Cambridge, UK, 2005.

17. Ravishankara, A.R.; Daniel, J.S.; Portmann, R.W. Nitrous oxide $\left(\mathrm{N}_{2} \mathrm{O}\right)$ : the dominant ozonedepleting substance emitted in the 21 st century. Science 2009, 326, 123-125.

18. Environmental Protection Agency (EPA). National Ambient Air Quality Standards; Washington, D.C., USA, 2011. www.epa.gov/air/criteria.

19. Perrino, C. Atmospheric particulate matter. Proceedings of a C ISB Minisymposium; Rome, Italy, March 2010.

20. Niisoe, T.; Nakamura, E.; Harada, K.; Ishikawa, H.; Hitomi, T.; Watanabe, T.; Wang, Z.; Koizumi, A. A global transport model of lead in the atmosphere. Atmospheric Environment 2010, 44, 1806-1814.

21. Goedkoop, M.; Oele, M.; de Schryver, A.; Vieira, M. SimaPro Database Manual: Methods library; PRé Consultants: Amersfoort, The Netherlands, 2008.

22. Bell, S.; Morse, S. Sustainability Indicators: Measuring the Immeasurable? Earthscan: London, UK, 2008.

23. Saldanha, N.; Beausoleil-Morrison, I. Measured end-use electric load profiles for 12 Canadian houses at high temporal resolution. Energy and Buildings 2012, 49, 519-530.

24. Zini, G.; Tartarini, P. Wind-hydrogen energy stand-alone system with carbon storage: modeling and simulation. Renewable Energy 2010, 35, 2461-2467.

2013 by the authors; licensee MDPI, Basel, Switzerland. This article is an open access article distributed under the terms and conditions of the Creative Commons Attribution license (http://creativecommons.org/licenses/by/3.0/). 